Constantin Bob

\title{
Multicriterial Hierarchy Methods Applied in Consumption Demand Analysis. The Case of Romania
}

\section{Summary}

The basic information for computing the quantitative statistical indicators, that characterize the demand of industrial products and services are collected by the national statistics organizations, through a series of statistical surveys (most of them periodical and partial). The source for data we used in the present paper is an statistical investigation organized by the National Institute of Statistics, "Family budgets survey" - that allows to collect information regarding the households composition, income, expenditure, consumption and other aspects of population living standard. In 2005, in Romania, a person spent monthly in average 391,2 RON, meaning about 115,1 Euros) for purchasing the consumed food products and beverage, as well as non-foods products, services, investments and other taxes. $23 \%$ of this sum was spent for purchasing the consumed food products and beverages, $21.6 \%$ of the total sum was spent for purchasing non-food goods and $18,1 \%$ - for payment of different services. There is a discrepancy between the different development regions in Romania, regarding total households expenditure composition. For this reason, in the present paper we applied statistical methods for ranking the various development regions in Romania, using the share of households' expenditure on categories of products and services - as ranking criteria.

\section{Total Consumption Expenditure by Regions}

The basic information for computing the quantitative statistical indicators, that characterize the demand of industrial products and services are collected by the national statistics organizations, through a series of statistical surveys (most of them periodical and selective). Such a survey is organized by the National 
Institute of Statistics, "Family budgets survey" - that allows to collect information regarding the households composition, income, expenditure, consumption and other aspects of population living standard. The survey is organized as a quarterly continuous research for a period of three successive months, on a sample of 9360 permanent dwellings, distributed in monthly independent sub-samples of 3120 permanent dwellings.

The survey has been carried out in 780 survey centers, distributed in all counties of the country and in Bucharest Municipality sectors (427 in urban area and 353 in rural area).

A household was included in a certain socio-economic category based on the main occupational status of the household reference person. Households were grouped by income deciles based on total income per persons, deflated by population consumer price index with January 2005 as base. The deciles divide the household series structured ascending according to the level of monthly average income per person into 10 equal parts (deciles groups).

For characterizing the demand of industrial products and services, we used the following statistical indicators:

- Total expenditure include:

- Money expenditure, irrespective of their destination (consumption, taxes and compulsory payments, purchases of animals and poultry, real estate and lands, other investment expenditure a.s.o) including equivalent value of free or at lower prices provisions (goods and services), evaluated at selling price of offering unit);

- Equivalent value of consumption of food and non-food products from own resources (production, stock a.s.o.) determined based on monthly average prices of respective products.

- Total consumption expenditure include:

- Money expenditure for buying consumed food products, non-foods goods and for payment of services, including equivalent value of free or at lower prices provisions (goods and services).

- Equivalent value of food and non-food products consumption from own resources.

- Yearly average consumption of food products per inhabitant expressed in physical units, represents the quantities of food products intended for human consumption regardless the consumption type (natural or processed), the supply source (food stores, free market, consumption from own resources a.s.o.) or the consumption place (individual households, restaurants, canteens, institutionalized households a.s.o.).

- Yearly average consumption of beverages, per inhabitant represents quantities of such products, consumed as average, per inhabitant in the reference year no matter of supply source (food stores, free market and own production of agricultural producers only for wine consumption) and of consumption place (population individual households, restaurants, canteens a.s.o.). 


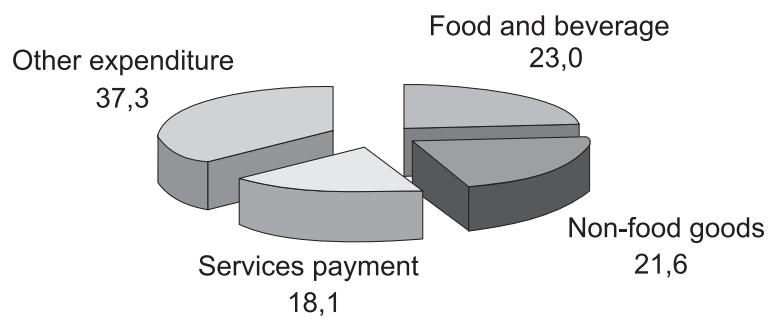

Figure 1. Total households expenditure composition in 2005 in Romania

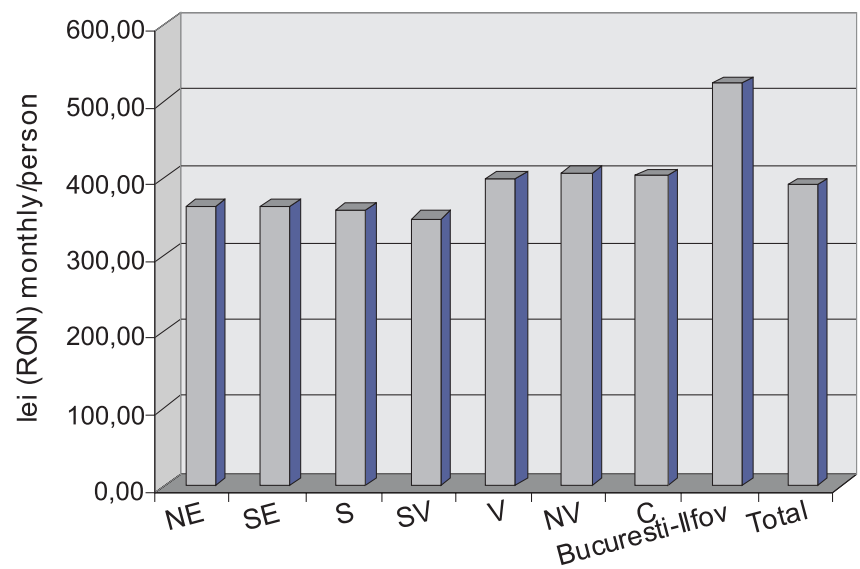

Development region

Figure 2. Total households expenditure in 2005 , for Romanian development regions

In 2005, in Romania, a person spent monthly in average 523,35 RON, for purchasing the consumed food products and beverages, as well as non-foods products, services, investments and other taxes. $23 \%$ of this sum was spent for purchasing the consumed food products and beverages, $21,6 \%$ of the total sum was spent for purchasing non-food goods and $18,1 \%$ - for payment of different services (figure 1).

Analyzing total households expenditure from Romania, in 2005, at territorial level, we conclude that in Bucharest-Ilfov Region the indicator registered its highest limit (with a total expenditure of 523.35 RON/pers., while in South-West Region it registered a minimum value (of 347,85 RON per person). Also, the Western Region, as well as the North-West and Central Region situated below the country average, but in the North-East, South-East and South Regions, one person spent in average a smaller amount of money than the country-average level (figure 2, table 1).

There can be sensed a discrepancy between the different development regions in Romania, regarding total households expenditure composition. The 
share of expenditure for purchasing food products and beverage in total expenditure reached the maximum value in the Western Region $(25,6 \%)$, followed by the Bucharest-Ilfov Region (25,3\%); the lowest share registered in the South-West Region (21,1\%). Referring to the share of expenditure for purchasing non-food products (clothes, shoes, durable goods a.s.o.) in total expenditure, the highest value registered in the North-West Region $23.1 \%$, followed by the Bucharest-Ilfov Region: 22,8\%. The minimum share of this category expenditure registered in the South-West Region (19,6\%). In 2005, it had been spent for services payment at most $24,5 \%$ of total monthly expenditure (per person) (in Bucharest) and at least 14,6\% (in South-West Region) (figure 3, table 2).

Analyzing dynamic behavior of monthly households consumption expenditure, we can conclude that during the 2001-2005 period, at macroeconomic level, the statistical indicator registered an increasing trend, the increase being more significant in Bucharest-Ilfov Region (with 176,07 RON in 2005 compared to 2001 , respectively with an annual average of 44,02 RON , at constant prices 2001). The evolution - positive, but slowly - of monthly households consumption expenditure - was registered in South-West Region, where the indicator increased (in 2005, compared to 2001) by 81,79 RON (respectively by an annual average of 20,45 RON) (Table 3, figure 4).

Table 1

\begin{tabular}{|c|c|c|c|c|c|c|c|c|c|}
\hline \multirow{2}{*}{$\begin{array}{c}\text { Development } \\
\text { region }\end{array}$} & Total & $\begin{array}{c}\text { North- } \\
\text {-East }\end{array}$ & $\begin{array}{c}\text { South- } \\
\text {-East }\end{array}$ & South & $\begin{array}{c}\text { South- } \\
\text {-West }\end{array}$ & West & $\begin{array}{c}\text { North- } \\
\text {-West }\end{array}$ & $\begin{array}{c}\text { Cen- } \\
\text { ter }\end{array}$ & $\begin{array}{c}\text { Bucha- } \\
\text { rest } \\
\text { Ilfov }\end{array}$ \\
\cline { 2 - 8 } & \multicolumn{8}{|c|}{ lei (RON), monthly on a person } \\
\hline Total expenditure (2005) & 391.2 & 365.36 & 363.90 & 358.32 & 347.85 & 400.67 & 407.10 & 403.78 & 523.35 \\
\hline
\end{tabular}

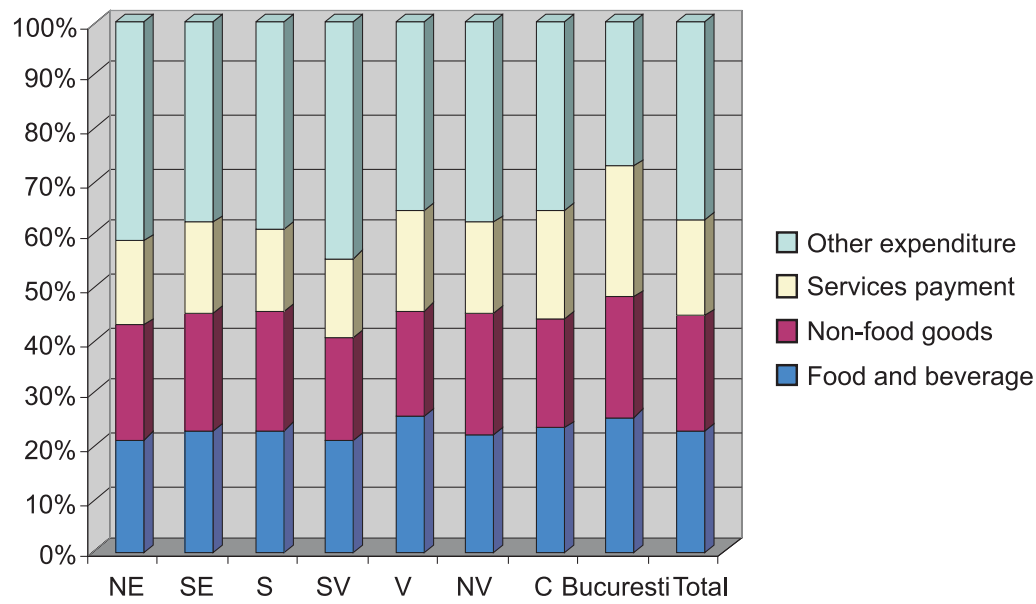

Figure 3. Total households expenditure composition in 2005 (\%) 
Table 2

\begin{tabular}{|l|c|c|c|c|c|}
\hline $\begin{array}{c}\text { Development } \\
\text { region }\end{array}$ & $\begin{array}{c}\text { Purchasing consumed } \\
\text { food products and } \\
\text { beverage }\end{array}$ & $\begin{array}{c}\text { Purchasing } \\
\text { non-food } \\
\text { products }\end{array}$ & $\begin{array}{c}\text { Services } \\
\text { payment }\end{array}$ & $\begin{array}{c}\text { Other } \\
\text { expenditure } \\
\text { categories }\end{array}$ & $\begin{array}{c}\text { Total } \\
\text { expenditure } \\
\text { (\%) }\end{array}$ \\
\hline North-East & 21.3 & 21.3 & 16.1 & 41.3 & 100 \\
\hline South-East & 23.0 & 22.1 & 17.2 & 37.7 & 100 \\
\hline South & 23.1 & 22.2 & 15.7 & 39.0 & 100 \\
\hline South-West & 21.1 & 19.6 & 14.6 & 44.7 & 100 \\
\hline West & 25.6 & 20.0 & 18.6 & 35.8 & 100 \\
\hline North-West & 21.8 & 23.1 & 17.2 & 37.9 & 100 \\
\hline Central & 23.4 & 20.6 & 20.4 & 35.6 & 100 \\
\hline Bucharest & 25.3 & 22.8 & 24.5 & 27.4 & 100 \\
\hline Total & 23.0 & 21.6 & 18.1 & 37.3 & 100 \\
\hline
\end{tabular}

Table 3. Monthly households consumption expenditure

\begin{tabular}{|l|c|c|c|c|c|}
\hline \multicolumn{7}{|c|}{ RON on a month, on a household - constant prices 2001 } \\
\hline Development region & $\mathbf{2 0 0 1}$ & $\mathbf{2 0 0 2}$ & $\mathbf{2 0 0 3}$ & $\mathbf{2 0 0 4}$ & $\mathbf{2 0 0 5}$ \\
\hline ROMANIA & 376.51 & $\mathbf{3 8 7 . 3 2}$ & 401.35 & 475.95 & 501.47 \\
\hline North-East & 336.25 & 354.66 & 373.57 & 456.99 & 479.72 \\
\hline South-East & 383.48 & 390.96 & 399.36 & 449.22 & 466.35 \\
\hline South & 359.14 & 354.91 & 364.08 & 443.41 & 457.82 \\
\hline South-West & 365.76 & 351.86 & 356.03 & 432.34 & 447.55 \\
\hline West & 366.23 & 371.64 & 391.98 & 496.63 & 512.14 \\
\hline North-West & 382.49 & 404.93 & 434.89 & 499.81 & 527.57 \\
\hline Central & 393.63 & 412.89 & 422.42 & 483.79 & 521.88 \\
\hline Bucharest-Ilfov & 449.96 & 476.60 & 490.07 & 569.34 & 626.03 \\
\hline
\end{tabular}

Figure 4.

Evolution of monthly households' consumption expenditure in

Romania 2001-2005

(constant prices-2001)

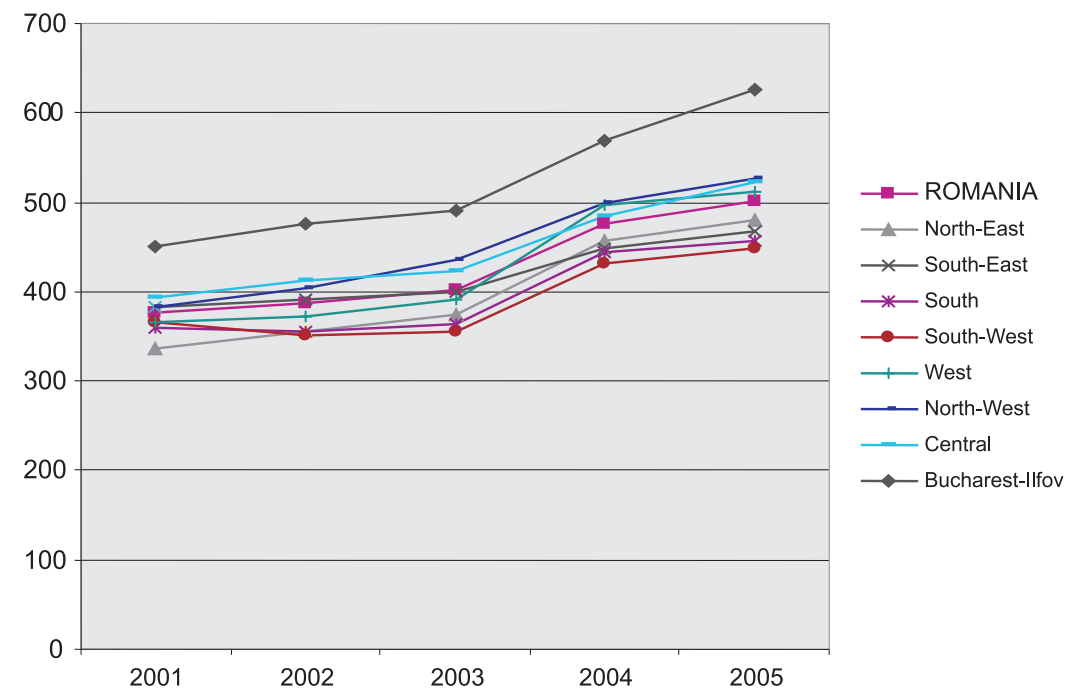


Table 4

\begin{tabular}{|l|c|c|}
\hline Development region & $\begin{array}{c}\text { Absolute difference in 2005 } \\
\text { compared to 2001 } \\
\text { (RON - const. prices) }\end{array}$ & $\begin{array}{c}\text { Annual average absolute } \\
\text { difference } \\
\text { (RON- const. prices/year) }\end{array}$ \\
\hline ROMANIA & 124.96 & 31.24 \\
\hline North-East & 143.47 & 35.87 \\
\hline South-East & 82.87 & 20.72 \\
\hline South & 98.68 & 24.67 \\
\hline South-West & 81.79 & 20.45 \\
\hline West & 145.91 & 36.48 \\
\hline North-West & 145.08 & 36.27 \\
\hline Central & 128.25 & 32.06 \\
\hline Bucharest-llfov & 176.07 & 44.02 \\
\hline
\end{tabular}

Analyzing the composition of total households' expenditure at territorial level, we proceed to a multicriterial hierarchy of development regions. The ranging criteria were the various expenditure categories: purchasing the consumed food-products and beverage, purchasing the non-food products and services payment.

These ranking criteria were expressed in a relative form, as structural (relative) indicators. They are computed in a $\frac{\text { part }}{\text { whole }}$ way, illustrating the statistical population composition by the studied variable. They are also named as weights, and computed according to the following relation:

$$
g_{i}^{x}=\frac{x_{i}}{\sum_{i=1}^{n} x_{i}}
$$

(expressed in coefficients)

or:

$$
g_{i \%}^{x}=\frac{x_{i}}{\sum_{i=1}^{n} x_{i}} \cdot 100
$$

Weights show the share of one variables' level (X) registered at a statistical unit or group of units " $i$ " $\left(x_{i}\right)$ in the total level of the variable $\left(\sum_{i=1}^{n} x_{i}\right)$. This relation can be computed only if the individual variables' levels can be summed. 
The sum of all weights computed for the same statistical population equals to 1 (if they are expressed in coefficients) or 100 (if they are expressed in per cents).

$$
\sum_{i=1}^{n} g_{i}^{x}=1 \quad \text { or } \quad \sum_{i=1}^{n} g_{i \%}^{x}=100
$$

If the whole population is divided into groups of units, and it had been computed the global variables' levels for each group, then the weight will be computed according to the formula:

$$
g_{i}^{x}=\frac{\sum_{j=1}^{n i} x_{i j}}{\sum_{i=1}^{r} \sum_{j=1}^{n i} x_{i j}}
$$

or:

$$
g_{i \%}^{x}=\frac{\sum_{j=1}^{n i} x_{i j}}{\sum_{i=1}^{r} \sum_{j=1}^{n i} x_{i j}} \cdot 100, \quad \text { (expressed in per cents) }
$$

where:

$n_{i}$ is the number of statistical units in a group " $i$ " of the population $(i=\overline{1, r})$;

$x_{i j}$ is the variable' level $\mathrm{X}$ for the unit $j$ of a group $i$;

$\sum_{j=1}^{n i} x_{i j}$ is the aggregated (total) variable level $\mathrm{X}$ for i group;

$\sum_{i=1}^{r} \sum_{j=1}^{n i} x_{i j}$ is the aggregated (total) variable level $\mathrm{X}$ for the whole population.

In this way we computed the total households expenditure composition, on different types of products and services.

In our analysis, we used a multicriterial hierarchy method: the ranking method.

\section{The Ranking Method and Some Empirical Results}

The ranking method consists of associating successively order numbers to every statistical territorial unit, according to the variable value or to the statistical indicators' value, registered at the respective unit. These variables represent the ranking criteria. The ranks are given as it follows: the territorial unit 
with the best performance will receive rank 1 , the unit with the following performance (in an descending order) - will receive rank 2 , then $3,4, \ldots n$ (where $n$ is the total number of units, or the sample volume, and also represents the rank assigned to the worse performance unit). If the statistical variable tends to get higher values, then the unit with the maximum variables' value gets rank 1 , while the one with the minimum variables' value - get rank $n$. In our paperwork, the ranking criteria are: the share of households' expenditure with purchasing food products and beverage in total households' expenditure, the share of households' expenditure with purchasing non-food products in total households' expenditure, the share of households' expenditure with services payment in total households' expenditure). If the most favorable level is represented by the lowest (minimum) variable value, then the unit with the minimum value gets the first rank, ..., the unit with the maximum value gets the " $n$ " rank. The ranks will be noted:

$$
\left\{R_{i} X_{j}\right\}, \quad i=\overline{1, n} ; \quad j=\overline{1, m} ;
$$

will represent the rank assigned to " $i$ " unit, according to the $X_{j}$ variable value; in our case, the territorial units consists of the development regions in Romania $(n=8)$, and $X_{j}$ represents the ranking criteria - shares of households expenditure, on different types of products and services $(m=3)$.

By summing all ranks assigned to a territorial unit, according to all variables values, we get a score. The score for " $i$ " development region is computed according to the relation:

$$
S_{i}=\sum_{j=1}^{m} R_{i}^{X j}, \quad i=\overline{1, n}
$$

The territorial unit with the lowest score ( $\min \left\{S_{i}, i=\overline{1, n}\right\}$ will be considered the most performant unit, from the ranking criteria point of view, and gets the final rank 1 . As the score get higher, the final rank will get higher, too, up to the „n” rank, assigned to the territorial unit with a maximum score.

Based on three ranking criteria (described above), and on ranking method application, we conclude that Bucharest-Ilfov is the highest situated - rank 1; the following regions are Central Region and Western region (both - rank 2.5). The worst placed region is the South-West region (rank 8), preceded by the North-Eastern region: rank 7).

The advantages of this method are a facile and a quick application, but it has a disadvantage, too: a double-leveling of the differences between the regions, by replacing them with an arithmetic progression with ratio 1 . A certain amount of qualitative information is - therefore - lost, the various distances between the territorial units being replaced by 1 ( 1 represents the distance between two successive ranks). 
Table 5. Development region hierarchy - ranking method

\begin{tabular}{|l|c|c|c|c|c|}
\hline \multirow{2}{*}{$\begin{array}{c}\text { Development } \\
\text { region }\end{array}$} & $\begin{array}{c}\text { Purchasing consumed } \\
\text { food products } \\
\text { and beverage }\end{array}$ & $\begin{array}{c}\text { Purchasing } \\
\text { non-food } \\
\text { products }\end{array}$ & $\begin{array}{c}\text { Services } \\
\text { payment }\end{array}$ & \multirow{2}{*}{ Score } & Final rank \\
\hline North-East & 7 & 5 & 6 & 18.0 & 7 \\
\hline South-East & 5 & 3 & 4,5 & 12.5 & 5 \\
\hline South & 4 & 4 & 7 & 15.0 & 6 \\
\hline South-West & 8 & 8 & 8 & 24.0 & 8 \\
\hline West & 1 & 7 & 3 & 11.0 & 2.5 \\
\hline North-West & 6 & 1 & 4,5 & 11.5 & 4 \\
\hline Central & 3 & 6 & 2 & 11.0 & 2.5 \\
\hline Bucharest & 2 & 2 & 1 & 5.0 & 1 \\
\hline
\end{tabular}

Analyzing the households' consumption expenditure composition, on different types of products and services, both at macroeconomic and regional level (development regions), for 2005 year, we conclude the following:

- in Romania, in 2005 44,2\% of consumption expenditure of one household represented expenditure with purchasing food-products and nonalcoholic drinks. The country average was outraged by South-West Region (48,7\%), by West Region (47,3\%), by North-East Region (45,8\%), South Region $(45,8 \%)$ and South-East Region $(44,5 \%)$,

- in Bucharest, $36,6 \%$ of total expenditure were spent on purchasing food-products and nonalcoholic drinks (the lowest share), representing almost 395 RON on a month, on a household,

- in South-West Region there were spent 7,9\% of total consumption expenditure for purchasing alcoholic drinks and tobacco (the greatest share), while in West Region - the lower share: $4,8 \%$,

- Bucharest inhabitants spent in average 53,925 RON (in a month, for a household) for purchasing clothes and shoes, representing 5\% of total expenditure sum (the minimum percent, compared to other regions); in North-East and in North-West Region it was spent a greater share $(7,4 \%)$ of total sum $(61,15$ RON in a month, for a household - in North-East Region, respectively $67,25 \mathrm{RON}$ in a month, for a household),

- Bucharest inhabitants spent a greater share of total expenditure sum on different types of services: dwelling, electricity, water, gas $(19,1 \%)$; for health services $(5,7 \%)$; for communications $(6,9 \%)$; for recreation and culture (5\%) and for education (1,2\%),

- Central Region inhabitants spent a maximum percent of total sum expenditure on purchasing furniture, house endowment and up keeping $(4,4 \%)$ and for transportation $(7,6 \%)$. 
Table 6. Households' consumption expenditure composition, on different types of products and services (\%)

\begin{tabular}{|l|c|c|c|c|c|}
\hline $\begin{array}{c}\text { Development } \\
\text { Regions }\end{array}$ & $\begin{array}{c}\text { Food-products } \\
\text { and nonalcoholic } \\
\text { drinks }\end{array}$ & $\begin{array}{c}\text { Alcoholic } \\
\text { drinks } \\
\text { and tobacco }\end{array}$ & $\begin{array}{c}\text { Clothes } \\
\text { and shoes }\end{array}$ & $\begin{array}{c}\text { Furniture, house } \\
\text { endowment and } \\
\text { up keeping }\end{array}$ & $\begin{array}{c}\text { Dwelling, } \\
\text { electricity, } \\
\text { water, gas }\end{array}$ \\
\hline North-East & 45,8 & 5,4 & 7,4 & 3,9 & 14,2 \\
\hline South-East & 44,5 & 5,6 & 6,1 & 3,6 & 15,2 \\
\hline South & 45,8 & 6,6 & 5,8 & 3,8 & 15,0 \\
\hline South-West & 48,7 & 7,9 & 6,6 & 2,8 & 14,0 \\
\hline West & 47,3 & 4,8 & 5,8 & 2,9 & 17,2 \\
\hline North-West & 43,6 & 5,5 & 7,4 & 4,0 & 14,7 \\
\hline Central & 43,0 & 5,6 & 5,6 & 4,4 & 15,9 \\
\hline Bucharest & 36,6 & 5,5 & 5,0 & 4,2 & 19,1 \\
\hline Total & 44,2 & 5,8 & 6,2 & 3,8 & 15,6 \\
\hline
\end{tabular}

Table 7. Households' consumption expenditure composition, on different types of products and services (\%)

\begin{tabular}{|l|c|c|c|c|c|}
\hline $\begin{array}{c}\text { Development } \\
\text { Regions }\end{array}$ & Health & Transportation & $\begin{array}{c}\text { Communica- } \\
\text { tions }\end{array}$ & $\begin{array}{c}\text { Recreation } \\
\text { and culture }\end{array}$ & Education \\
\hline North-East & 4,2 & 5,5 & 4,1 & 4,2 & 0,9 \\
\hline South-East & 3,8 & 7,3 & 4,7 & 3,8 & 1,0 \\
\hline South & 4,3 & 6,5 & 4,1 & 4,0 & 0,6 \\
\hline South-West & 2,4 & 5,5 & 4,1 & 3,6 & 0,7 \\
\hline West & 2,6 & 6,0 & 4,8 & 4,1 & 0,6 \\
\hline North-West & 3,4 & 7,2 & 4,9 & 4,3 & 0,9 \\
\hline Central & 3,4 & 7,6 & 5,0 & 4,4 & 0,8 \\
\hline Bucharest & 5,7 & 6,0 & 6,9 & 5,0 & 1,2 \\
\hline Total & 3,8 & 6,5 & 4,9 & 4,2 & 0,9 \\
\hline
\end{tabular}

\section{Industrial Policy Implications}

According to the European Commission, in Romania there can be noticed some progress in creating a functional market economy, but in spite of this, EU is reserved in Romania's capability (on medium term) to face the competition pressure and labor forces within the Union. There are several weak-points of manufacturing industry in Romania:

- the dependence on "forced exports";

- the absence of enforcing the technological specialization in production and exports; 
- the persistency of „negative added value” syndrome in certain industries;

- insignificant influence (until now) of direct foreign investments;

- slow progress in ensuring the job security, of export certification, of ISO certification.

For the Romanian Government, the strategic objective of the industrial policy is the increase of competitiveness and the performances of the Romanian industry within the European and world context. Romania's industrial policy will be elaborated taking into account the national interest, to the public benefit and in comply with the citizen's security. The overall objectives of the industrial policy are:

- Increase of competitiveness;

- Increase of the role of research and development;

- Promotion of a durable management of resources and environment protection;

- Improvement of the professional training and labor employment.

These objectives can be achieved only if Romania's industrial policy observes the rules of the knowledge economy adopted at Lisbon in 2000. At the same time, we have to mention that further to EU enlargement and election of a new European Commission there has been created a new structure in charge with elaborating a new European industrial policy, in the context in which there are only two directives with compulsoriness character in the field. According to the Government, the instruments for the implementation of Romania's new industrial policy are: sector assistance, privatization and restructuring, assistance for export, supporting regional development, access to information and treating the externalities.

\section{References}

Croitoru L., Schaffer M., Soft Budget Constraints in Romania: Measurement, Assessment, Policy, The Romanian Centre for Economic Policies, 2002.

Dobrescu E., Economic growth rates, Political Publishing House, Bucharest 1968.

Pack H., Industrial Policy: Growth Elixir or Poison?, World Bank Research, "Observer", vol. 15, 2000 no. 1.

Peneder M., Entrepreneurial Competition and Industrial Location, Edward Elgar, 2001.

Porter M.E., The Competitive Advantage of Nations, The Free Press, New York 1990.

Isaic-Maniu Al, Mitrut C., Voineagu V., Statistics for Business Management, Economic Publishing House, Bucharest 2005.

Methodology of Short-term Business Statistics, Office for Official Publications of the European Communities, Luxembourg, European Communities, EUROSTAT, 2006.

European Commission Country Report 2003, European Commission Delegation in Romania, European Union, Bucharest, 2003, November the $5^{\text {th }}$.

Statistical Yearbook of Romania, National Institute of Statistics, 2005, 2006. 


\section{Zastosowanie wielokryterialnych metod analizy popytu konsumpcyjnego. Przykład Rumunii}

\section{Streszczenie}

Podstawowe, cykliczne i okresowe dane dotyczqce ksztattowania się popytu na produkty $i$ ustugi podawane sa przez narodowe urzędy statystyczne. Umożliwia to kalkulacje licznych wskaźników statystycznych. Artykut jest oparty na tego typu danych, przedstawionych przez rumuński Narodowy Urzqd Statystyczny w raporcie pt. „Przeglad budżetu gospodarstw domowych”. Na podstawie tego raportu można ocenić m.in. dochody, wydatki, poziom konsumpcji rumuńskich gospodarstw domowych oraz zmiany, jakie zaszty $w$ ostatnim czasie $w$ tym zakresie. W 2005 r. przeciętna wartość miesięcznych wydatków jednej osoby, zarówno na żywność, jak i inne dobra konsumpcyjne, ustugi, podatki i inwestycje wynosiła 391,2 RON (115,1 EUR). 23\% tej kwoty gospodarstwa domowe przeznaczaty na dobra konsumpcyjne pierwszej potrzeby (gtównie żywność), 21,6\% - na inne dobra konsumpcyjne, a 18,1\% na optacenie różnego typu ustug. W statystykach tych występuje zróżnicowanie między regionami kraju. W zwiazku z tym, $w$ artykule zaproponowano metody statystyczne analizy wielokryterialnej uszeregowania wydatków gospodarstw domowych wedtug regionów kraju tak, aby wyniki analiz mogty być ze sobq bardziej porównywalne. 